\title{
Tables, Maps, and Charts
}

TABLES

1 World Oil Consumption and Exports, 1938-1973 15

2 Sources and Volume of Petroleum Hydrocarbons Entering the Oceans, $1973 \quad 17$

3 Sources and Volume of Ship-Generated Oil Discharges, $1973 \quad 18$

4 World Tanker Registry, 1955-1975 56

5 Participation in IMCO's Open Committees and Conferences 63

6 Cost Estimates for the Torrey Canyon Spill 146

MAPS

1 Main Oil Movements by Sea, 1956 and 1976

2 Estimated Proportion of Petroleum-Derived Hydrocarbons in Total Hydrocarbons of Surface Water

\section{CHARTS}

1 IMCO Structures Concerned with Marine Pollution

2 IMCO Membership

3 Membership in IMCO's Elective Bodies

4 State Positions on General and Zonal Prohibitions at 1954 Conference

5 State Positions on British Proposal for Vessels above 20,000 Tons, 1962

6 State Positions on Major U.S. Technical Proposals at 1973 Conference

7 State Positions on Retrofitting Segregated

Ballast Tanks vs. Crude-Oil-Washing, 1978

8 Public Law Convention: Proposals and State Positions

9 Indicative Votes on Nature of Liability and Party Liable, and Limits of Liability 
10 State Positions on Deletion of Exceptions to Compensation

11 State Positions on the Role of the Fund in Indemnifying Shipowners

12 International Provisions for Compensation for Oil Pollution Damage

13 State Positions on "Special Measures"' Compromise

14 Compliance Measures Accepted, 1954-1973

15 Compliance Measures Rejected, 1954-1973

16 State Positions on Port-State Enforcement

17 Ratifications by IMCO Members (to November 1977)

A World Nontanker Registry, 1955-1975

B Major Exporters of Oil (Crude and Refined) by Sea, $1973 \quad 369$

C Major Importers of Oil (Crude and Refined) by Sea, $1973 \quad 370$

D Major Traders of Dry Cargo Goods by Sea, 1973

E Percentage of States' Tanker Tonnage Owned by Oil Companies, 1973

F National Registry of Tankers of the Seven Major Western Oil Companies 